Turyzm 2004, $\quad 14 / 2$

\author{
Blanka Gosik \\ Studium Doktoranckie \\ Uniwersytet Łódzki \\ 90-142 Łódź, ul. Kopcińskiego 31
}

\section{CMENTARZE \\ Z I WOJNY ŚWIATOWEJ JAKO WALOR ANTROPOGENICZNY OKOLICY LODZI}

\section{WSTEP}

Region łódzki posiada dużą liczbę walorów turystycznych, zarówno przyrodniczych, jak i antropogenicznych. W dużej mierze wynika to z położenia geograficznego, a także z bogatej i ciekawej przeszłości obszaru. Niestety, w bardzo szerokiej ofercie turystycznej nie uwzględnia się cmentarzy wojskowych, a w szczególności miejsc pochówku z okresu I wojny światowej.

Cmentarze wojskowe należą do grupy zasobów i walorów pozaprzyrodniczych - antropogenicznych. Walory te dzielą się wg LIJEwSKIEGO i wsp. (1985) na podgrupy; badane obiekty należą do grupy obiektów historyczno-wojskowych.

\section{CMENTARZE WOJENNE JAKO PRZYKŁAD KULTURY MATERIALNEJ}

„Ojczyzna to ziemia i groby. Narody tracąc pamięć tracą życie". Te słowa przypisuje się marszałkowi Ferdinandowi Fochowi, jednemu z ważniejszych dowódców z okresu I wojny światowej. Foch miał słuszność, gdyż cmentarze i groby są bardzo wymownym obrazem dziejów narodowych, zarówno okresu pokoju, jak i czasu wojny. Właśnie ta żołnierska śmierć jest jedną z najbardziej tragicznych śmierci. Polegli żołnierze, pochowani $\mathrm{z}$ dala od miejsca zamieszkania, często w obcym kraju, w ogromnej większości pozostają anonimowi. Dlatego na początku XX w. powstała bardzo słuszna

\section{WORLD WAR I CEMETERIES AS AN ANTHROPOGENIC RESOURCE FOR THE ŁÓDŹ REGION}

\section{INTRODUCTION}

The Łódź region is full of tourist resources both natural and anthropogenic largely from its geographical location as well as from its rich and interesting past. Unfortunately this wide tourist offer does not include military cemeteries, and those from the times of World War I in particular. Military cemeteries are nonnatural, anthro-pogenic tourist resources and attractions. According to LIJEWSKI et al. (1985) cemeteries are a sub-group of the wider category of historical and military sites.

\section{WAR CEMETERIES AS A CULTURAL RESOURCE}

"A fatherland is found in its soil and its graves. In the loss of memory a nation loses its life". The words of Marshal Ferdinand Foch, one of the commanders-in-chief from World War I. Foch was right, cemeteries and graves provoke strong reflections on national history in times of both peace and war. A soldier's death is one of the most tragic deaths. Buried far from home and often in a foreign land, fallen soldiers in great numbers remain anonymous. As a result in the early $20^{\text {th }} \mathrm{c}$. the very good 
idea - powszechne stawianie Grobu Nieznanego Żołnierza. W całej Europie groby te są symbolem i jednocześnie hołdem dla poległych za ojczyznę. Jako pierwsza, Grób Nieznanego Żołnierza postawiła Francja - w 1920 r. pod Łukiem Triumfalnym. W Polsce, taki grób-pomnik wybudowano w 1925 r., na placu Saskim w Warszawie. Z wydarzeniem tym związana jest wzruszająca historia wyboru trumny ze zwłokami mającymi spocząć na placu Saskim dokonała kobieta, która straciła syna podczas jednej $\mathrm{z}$ bitew i nigdy nie odnalazła jego mogiły (KolBUSZEWSKI 1996). Cmentarze wojskowe są stosunkowo młodym tworem sztuki sepulkralnej. Pierwszy na świecie, planowo założony obiekt tego typu znajduje się w Arlington w Stanach Zjednoczonych. Nekropolia powstała w konsekwencji wojny secesyjnej i liczyła ok. 16 tys. nagrobków. W Europie pierwsze cmentarze wojskowe powstały w trakcie i po skończeniu I wojny światowej. Odznaczają się one piękną architekturą i bogatą stylistyka. Niestety, z biegiem czasu pamięć o nich powoli się zaciera. W dużym stopniu przyczynił się do tego wybuch II wojny światowej, która przyniosła ze sobą ogromną liczbę ofiar i cmentarzy. Trudno się temu dziwić, gdyż tragizm ostatniej wojny jest nam bliższy i cały czas żywy we wspomnieniach świadków tamtego okresu.

Wszystkie miejsca pochówku żołnierskiego, niezależnie od kraju w jakim się znajduja, łączy jednorodność pomników nagrobnych i równomiernie rozmieszczone groby. Sprawia to wrażenie monotonii, ale jednocześnie nadaje nekropoliom wojskowym pewien niepowtarzalny charakter. Jednocześnie podniosłość i tragizm cmentarzy żołnierskich podkreślają licznie używane symbole - orły, hełmy, miecze, kamienne posągi itp.

\section{WOJENNE MIEJSCA POCHÓWKU W OKOLICY LODZI}

Na przełomie listopada i grudnia 1914 r. na terenie Królestwa Polskiego odbywały się walki, uważane przez znawców za najcięższe i najbardziej krwawe w pierwszej fazie I wojny światowej. Z Łodzią, która znajdowała się w centrum działań wojennych, związana jest ich nazwa. Historiografia rosyjska nadała walkom nazwę todzinskaja opieracija, polska operacja tódzka, a propaganda niemiecka die Schlacht bei Lodz. W dniach 19-24 listopada rozegrał się ostatni etap operacji łódzkiej, zwany „bitwą pod Brzezinami” (RóżYCKI idea of erecting a 'Tomb for an Unknown Soldier' came into being. Throughout Europe these tombs are symbols, and also homage, paid to those who died for their countries with the first being erected in France in 1920 under the Arc de Triomphe. In Poland such a tomb was placed in Warsaw's Plac Saski in 1925. A moving story accompanies this event; the choice of the coffin that was to be buried there was made by a woman who had lost her son in one of the battles but had never found his grave (KOLBUSZEWSKI 1996).

Military cemeteries and their sepulchral art are relatively new. The first was founded at Arlington in the USA with about 16000 graves set up as a consequence of the American Civil War. The first in Europe were set up during and after World War I and contain beautiful architecture in an opulent style. Unfortunately with time they have been slowly forgotten, largely due to World War II which brought great numbers of further victims and cemeteries. This is not surprising as the atrocities of the last war are closer and still live in the memories of witnesses to those events.

All military cemeteries, regardless of the countries where they were established, are characterised by a uniformity of gravestones and orderly regimentation of graves. This may give an impression of monotony, but at the same time these cemeteries have a certain unique character. Their sublimity and tragic nature are highlighted by the frequently used symbols of eagles, helmets, swords, and the stone statues etc.

\section{WAR CEMETERIES AROUND ŁÓDŹ}

In November and December 1914 bloody battles took place that are regarded by historians as the hardest and cruellest in the first phase of World War I. Their collective name - Operation Łódź - is associated with the city which was at their centre. Russian history calls them todzinskaja opieracija, in Polish Operacja Łódzka and German propaganda called them die Schlacht bei Lodz. On 19th $24^{\text {th }}$ November the Battle of Brzeziny, the last stage of Operation Łódź, took place 
1936). W literaturze niemieckiej bitwa ta nazywana jest Durchbruch bei Brzeziny, czyli przełamanie pod Brzezinami. Bitwa swoim zasięgiem nie ograniczała się tylko do samego rejonu Brzezin. Składały się na nią wszystkie działania wojenne prowadzone w tych dniach w okolicy Łodzi pomiędzy 9 armią niemiecką a 1, 2 i 5 armią rosyjską (DĄBROWSKI, 1937) od Piotrkowa i Będkowa na południu, Pabianic, Konstantynowa i Aleksandrowa na zachodzie, po Stryków, Zgierz, a nawet Ozorków na północy. Rezultatem operacji łódzkiej był również podział regionu na dwa obszary okupacyjne: niemiecki i austriacki. Granica między nimi przebiegała na północ od Piotrkowa i Wielunia.
(RóżYCKI 1936). The battle was not limited to the Brzeziny region, but included all movements of the German $9^{\text {th }}$ army and the Russian $1^{\text {st }}, 2^{\text {nd }}$ and $5^{\text {th }}$ armies around Łódż (DA̧BROWSKI 1937) from Piotrkow and Będkow in the south, through Pabianice, Konstantynów and Aleksandrów in the west, to Strykow, Zgierz and even Ozorkow in the north. One result of Operation Łodż was the division of the region into two occupation zones: German and Austrian, with the border running to the north of Piotrków and Wielun.
Rys. 1. Wojskowe miejsca pochówku z okresu I wojny światowej w okolicach Łodzi

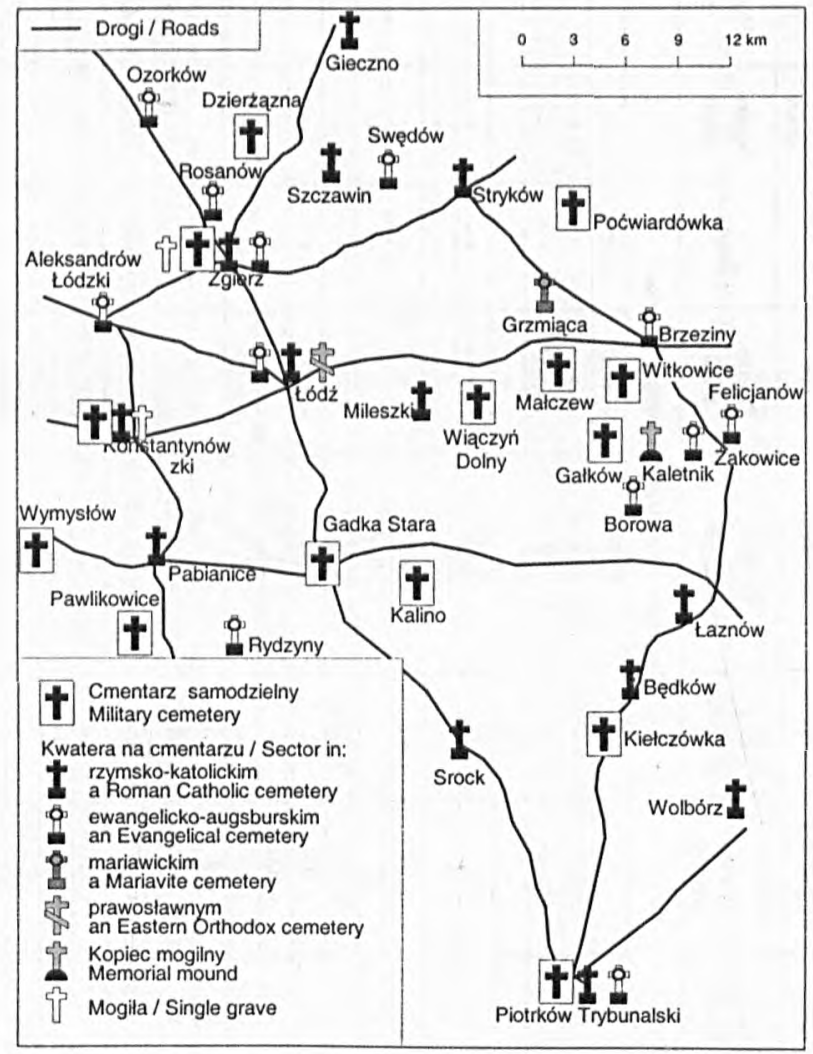

Fig. 1. Military burial places from the World War I period in the vicinity of Łódż
Materialnym odzwierciedleniem tamtych krwawych zdarzeń są opisane w dalszej części wojskowe miejsca pochówku. W maju 2003 r. udokumentowanych i upamiętnionych obiektów tego typu w całym województwie łódzkim było 176. Nie jest to stała liczba, ponieważ cały czas odkrywane są nowe miejsca pochówku żołnierzy poległych podczas I wojny światowej. Oprócz upamiętnionych obiektów cmentarnych, istnieje nie ustalona liczba obiektów nie upamiętnionych, których nie można zlokalizować w terenie. Są to miejsca udokumentowane jedynie archiwalnie, na których często dokonywane
The military cemeteries described below are material relics of those bloody events. In May 2003, throughout Łódź Województwo, there were 176 documented and commemorated cemeteries of this type. The total is not fixed as new places of burial are still being discovered and there are an undefined number which cannot be found. These exist only in the archives, very often new burials overlie them, or they have been moved or simply plundered and destroyed. In the area 
$T a$ b $\in$ Ia I. Tabela inwertaryzacyjno-waloryzacyjna cmentarzy z okresu I wojny światowej w regionie tódzkim (stan w $2003 \mathrm{r}$.)

T a b le I. Cemeteries from the World War I period in the Lodź region - ranked catalogue (for 2003)

\begin{tabular}{|c|c|c|c|c|c|c|c|c|c|c|c|c|c|c|}
\hline $\begin{array}{l}\text { Nazwa } \\
\text { miejsca }\end{array}$ & $\begin{array}{c}\text { Tablica } \\
\text { informa- } \\
\text { cyjna }\end{array}$ & $\begin{array}{l}\text { Obiekt } \\
\text { central- } \\
\text { ny }\end{array}$ & $\begin{array}{l}\text { Inskryp- } \\
\text { cje }\end{array}$ & $\begin{array}{c}\text { Liczba } \\
\text { nagrobków }\end{array}$ & $\begin{array}{l}\text { Liczba } \\
\text { krzyży }\end{array}$ & $\begin{array}{c}\text { Materiał } \\
\text { budowlany }\end{array}$ & $\begin{array}{l}\text { Ogrodze- } \\
\text { nie }\end{array}$ & Bramy & $\begin{array}{l}\text { Prace } \\
\text { porzad- } \\
\text { kowe }\end{array}$ & $\begin{array}{l}\text { Wpis do } \\
\text { rejestru } \\
\text { zabudowy }\end{array}$ & $\begin{array}{l}\text { Liczba } \\
\text { pocho- } \\
\text { wanych }\end{array}$ & $\begin{array}{l}\text { Powierz- } \\
\text { chnia (w ha) }\end{array}$ & $\begin{array}{l}\text { Liczba } \\
\text { punktów }\end{array}$ & Ranga \\
\hline Place & $\begin{array}{l}\text { Informa- } \\
\text { tion } \\
\text { board }\end{array}$ & $\begin{array}{l}\text { Central } \\
\text { Monu- } \\
\text { ment }\end{array}$ & $\begin{array}{l}\text { Inscrip- } \\
\text { tions }\end{array}$ & $\begin{array}{l}\text { No of } \\
\text { grave- } \\
\text { stones }\end{array}$ & $\begin{array}{l}\text { No of } \\
\text { crosses }\end{array}$ & $\begin{array}{l}\text { Building } \\
\text { material }\end{array}$ & $\begin{array}{l}\text { Bound- } \\
\text { aries }\end{array}$ & Gates & $\begin{array}{l}\text { Resto- } \\
\text { ration }\end{array}$ & $\begin{array}{l}\text { Register } \\
\text { entry }\end{array}$ & $\begin{array}{l}\text { No of } \\
\text { bodies }\end{array}$ & Area (ha) & $\begin{array}{l}\text { Point } \\
\text { score }\end{array}$ & Rank \\
\hline \multicolumn{15}{|c|}{ Cmentarz samodzielny / Military cemetery } \\
\hline Dzierżazna & - & - & + & 13 & - & $\mathrm{C}, \mathrm{S}$ & + resid. & + resid. & - & - & 130 & 0.12 & 12 & IIII \\
\hline Gadka Stara & + & 0 & + & $>130$ & - & $\mathrm{C}, \mathrm{G}, \mathrm{Z}, \mathrm{S}$ & + & + & + & + & c. 2000 & 5.2 & 33 & 1 \\
\hline Gałków Las & - & B & + & 4 resid. & - & $\mathrm{C}, \mathrm{B}$ & + resid. & - & - & - & 500 & 0.5 & 14 & III \\
\hline Kalino & - & - & - & - & 2 & Z & + & - & - & - & 41 & 0.001 & 10 & III \\
\hline Kiełczówka & - & - & + & 11 & 35 & $\mathrm{C}, \mathrm{Z}$ & + & + & + & - & 88 & 0.07 & 20 & 1 \\
\hline Małczew & + & - & + & - & - & $\mathrm{C}, \mathrm{S}$ & - & - & - & - & n. d. & n.d. & 10 & III \\
\hline Pawlikowice & - & - & + & $>65$ & $>5$ & $C, W$ & - & - & - & - & c. 500 & 0.52 & 15 & II \\
\hline Piotrków Trybunalski & - & B & + & 99 & - & $\mathrm{C}, \mathrm{B}, \mathrm{Z}$ & + & + & + & - & n.d. & 0.005 & 21 & 1 \\
\hline Poćwiardówka & + & 0 & + & $>215$ & 3 resid. & $\mathrm{C}, \mathrm{W}, \mathrm{S}, \mathrm{M}$ & - & - & + & - & n.d. & 1.25 & 25 & 1 \\
\hline Rszew Legionowo & - & - & + & $>90$ & 1 & $\mathrm{C}, \mathrm{W}$ & + resid. & - & - & - & $>874$ & 1.7 & 14 & III \\
\hline Wiaczyń Dolny & + & 20 & + & $>400$ & - & $\mathrm{C}, \mathrm{B}, \mathrm{G}, \mathrm{S}, \mathrm{Z}$ & + & + & + & - & C. 1977 & 1.02 & 28 & 1 \\
\hline Witkowice & - & 0 resid. & + & $>15$ & - & $C, B, S$ & + resid. & + resid. & - & - & n.d. & 3.4 & 17 & II \\
\hline Wymystów Piaski & + & 0 & + & 114 & 1 & $\mathrm{C}, \mathrm{W}, \mathrm{M}, \mathrm{Z}$ & + & - & + & - & 725 & 1.1 & 24 & 1 \\
\hline Zgierz-Krogulec & - & $\mathrm{B}, 2 \mathrm{~K}$ & + & - & 14 & $\mathrm{C}, \mathrm{B}, \mathrm{G}, \mathrm{S}, \mathrm{W}$ & + & + & + & - & 319 & 0.78 & 19 & 1 \\
\hline \multicolumn{15}{|c|}{ Kwatery wojskowe na cmentarzach rzymskokatolickich / Military sectors in Roman Catholic cemeteries } \\
\hline Będków & - & - & + & 5 & - & $\mathrm{C}$ & - & - & + & - & c. 100 & 0.005 & 12 & III \\
\hline Gieczno & - & - & + & - & 1 & W & 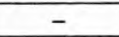 & - & $\begin{array}{ll}- \\
\end{array}$ & - & 1 & 0.0002 & 11 & III \\
\hline Konstantynów, ul. Łaska & - & - & + & 2 & - & $C$ & - & - & - & - & 2 & 0.0004 & 11 & III \\
\hline taznów & - & - & + & 5 & 1 & $\mathrm{C}, \mathrm{Z}$ & - & - & - & - & n.d. & 0.0008 & 11 & III \\
\hline Łódź-Mileszki & - & - & + & 1 & - & $S$ & - & - & + & - & 35 & 0.0002 & 10 & III \\
\hline Łódż, ul. Rzgowska & + & - & - & - & - & $\mathrm{L}$ & - & - & + & - & 7 & 0.0025 & 11 & III \\
\hline Pabianice & - & - & + & 1 & - & $\mathrm{C}$ & - & - & - & - & 48 & 0.0004 & 10 & III \\
\hline $\begin{array}{l}\text { Piotrków Trybunalski - } \\
\text { "nowy cmentarz"/ 'new' } \\
\text { cemetery }\end{array}$ & + & B & - & - & - & $B, M$ & - & - & + & - & $>443$ & 0.036 & 13 & III \\
\hline Srock & + & $B$ & + & 1 & 6 & $\mathrm{~B}, \mathrm{G}, \mathrm{Z}$ & - & - & + & - & c. 400 & 0.0012 & 19 & 1 \\
\hline Stryków & + & - & - & - & - & $\mathrm{L}$ & $\begin{array}{ll}- \\
-\end{array}$ & - & + & - & 279 & 0.005 & 11 & IIII \\
\hline Szczawin & - & - & + & 15 & - & $\mathrm{C}$ & - & - & + & - & c. 150 & 0.025 & 12 & III \\
\hline Wolbórz & - & - & + & - & 19 & $Z$ & - & - & + & - & n.d. & n.d. & 12 & III \\
\hline Zgierz, ul. Skargi & - & - & - & 23 & - & L & - & - & + & - & 27 & 0.0288 & 11 & III \\
\hline
\end{tabular}




\begin{tabular}{|c|c|c|c|c|c|c|c|c|c|c|c|c|c|c|}
\hline \multicolumn{15}{|c|}{ Kwatery wojskowe na cmentarzach ewangelicko-augsburskich / Military sectors in Evangelical cemeteries } \\
\hline Aleksandrów Łódzki & - & 0 & + & 9 & - & $\mathrm{C}, \mathrm{S}$ & - & - & + & - & 38 & 0.068 & 13 & IIII \\
\hline Borowa & - & - & + & 3 & - & $B$ & - & - & - & - & n. d. & n.d. & 10 & III \\
\hline Brzeziny & - & - & $\begin{array}{ccc}+ \\
+\end{array}$ & $>30$ & - & C & - & - & - & + & n. d. & 0.009 & 12 & III \\
\hline Felicjanów & - & - & + & 2 & - & c & - & - & - & - & 4 & 0.0002 & 8 & IV \\
\hline Łódż-Laskowice & - & - & + & 1 & - & c & - & - & - & - & n.d. & 0.0002 & 8 & IV \\
\hline Ozorków & - & - & + & 14 & - & $\mathrm{C}$ & - & - & - & - & c. 36 & 0.009 & 12 & III \\
\hline Piotrków Trybunalski & - & $\mathrm{B}, \mathrm{K}$ & + & $>57$ & 1 & $C, W, B$ & - & - & - & - & 400 & 0.03 & 17 & II \\
\hline Rosanów & - & - & - & 2 & - & $\mathrm{C}$ & - & - & - & - & 2 & 0.0002 & 8 & IV \\
\hline Rydzyny & - & - & + & 2 & - & $\mathrm{C}$ & - & - & - & - & 4 & 0.0004 & 10 & IIII \\
\hline Swędów & - & - & + & 14 & - & $C$ & - & - & - & - & c. 60 & 0.005 & 12 & III \\
\hline Zgierz, ul. Spacerowa & + & $0, K$ & + & 14 & 1 & $\mathrm{C}, \mathrm{G}, \mathrm{Z}, \mathrm{P}$ & - & - & + & - & c. 100 & 0.003 & 20 & 1 \\
\hline Żakowice & - & - & + & 4 & - & $\mathrm{C}$ & - & - & - & - & 6 & 0.0005 & 8 & IV \\
\hline \multicolumn{15}{|c|}{ Kwatery wojskowa na cmentarzu mariawickim / Military sector in a Mariavite cemetery } \\
\hline Grzmiąca & - & - & + & 1 & - & $\mathrm{C}$ & - & - & - & - & 3 & 0.0006 & 11 & IIII \\
\hline \multicolumn{15}{|c|}{ Kwatery wojskowe na cmentarzu prawosławnym / Military sector in an Eastern Orthodox cemetery } \\
\hline Łódż, ul. Telefoniczna & + & - & + & 49 & 7 & $\mathrm{C}, \mathrm{Z}$ & - & - & + & - & 1151 & 0.2 & 22 & 1 \\
\hline \multicolumn{15}{|c|}{ Mogity / Individual graves } \\
\hline $\begin{array}{l}\text { Konstantynów Łódzki, } \\
\text { ul. Kościelna }\end{array}$ & - & - & + & 4 & - & C & - & - & + & - & 4 & 0.0008 & 11 & III \\
\hline Zgierz-Aniołów & - & - & + & 1 & - & $\mathrm{C}, \mathrm{W}$ & + & - & + & - & 2 & 0.0002 & 13 & III \\
\hline \multicolumn{15}{|c|}{ Kopiec mogilny / Unmarked mounds } \\
\hline Kaletnik & - & $K$ & - & 0 & 1 & W & - & - & + & - & n.d. & 0.01 & 10 & III \\
\hline
\end{tabular}

C - beton, Z - żeliwo, W - drewno, B - głaz, G - granit, S-kamień, L - lastriko, M - marmur, P- piaskowiec; O - obelisk, K - krzyż; n. d. - nieznana, (+) - element wystẹpuje, (-) - element nie występuje, > nie mniej niż, resid. - element występuje w stanie szczątkowym, c. - circa, około; I - walory bardzo wysokie, II - walory wysokie, III - walory średnie, IV - walory niskie.

Żródło: Opracowanie własne.

C - concrete, Z - cast iron, W - wood, B - boulder, G - granite, S - stone, L - mosaic, M - marble, $\mathrm{P}$ - sandstone; $\mathrm{O}$ - obelisk, $\mathrm{K}$ - cross; ul. - street; $n$. d. - unknown number or area, (+) - element present, (-) - element absent, > - not less than, resid. - residual; $\mathrm{c}$. - circa; I - very high value, II - high value, III - medium value, IV - low value.

Source: Author. 
są nowe pochówki, zostały przeniesione lub po prostu zdewastowane i rozkradzione. Na obszarze badań (teren bitwy pod Brzezinami) znajdują się 44 obiekty udokumentowane: cmentarze samodzielne, kwatery, mogiły, kopce mogilne (rys. 1) i ok. 50 obiektów nie upamiętnionych. Tabela I przedstawia inwentaryzację badanych obiektów. Karta inwentaryzacyjna zawiera informacje ilustrujące stan obecny obiektów i prezentuje wyniki badań terenowych przeprowadzonych $w$ okresie od sierpnia 2002 do maja 2003 r.

\section{ZAKZADANIE I BUDOWA CMENTARZY Z I WOJNY ŚWIATOWEJ}

I wojna światowa pochłonęła miliony niewinnych ofiar. W regionie Łodzi polegli wywodzili się z wrogich armii. Byli to: Rosjanie, Niemcy, Austriacy, Węgrzy, a także Polacy, Ukraińcy, Słowacy, Czesi. Bardzo szybko pojawił się problem zapewnienia poległym należytych miejsc pochówku. W rejonie Łodzi, bezpośrednio po zakończeniu działań wojennych, porządkowaniem pobojowisk obarczono ludność cywilną i specjalne oddziały wojskowe. Pojawiły się instytucje zajmujące się organizowaniem cmentarzy wojskowych. Działalność tych instytucji była $w$ ramach propagandy austriackiej i niemieckiej wyolbrzymiana i idealizowana. Ogłaszano specjalne konkursy na projekty kaplic cmentarnych, nagrobków, krzyży. Wyjątkową dbałością obejmowano miejsca po wygranych bitwach, które w przyszłości mają być odwiedzane przez potomnych. Sam proces powstawania i organizowania cmentarzy wyglądał podobnie na terenie obu stref okupacyjnych. O jak najszybszym rozpoczęciu prac zadecydowało kilka względów. Kierowano się w dużej mierze względami higienicznymi, gdyż nie zabezpieczone groby zanieczyszczając wodę sprzyjały powstawaniu epidemii tyfusu, cholery i innych chorób zakaźnych. Drugim argumentem przemawiającym za szybkim tworzeniem cmentarzy było wykorzystanie taniej siły roboczej, jaką stanowili jeńcy, a także ludzi sztuki powołanych ,pod broń" (SCHUBERT 1992). Wielu rzeźbiarzy, architektów czy malarzy wolało służyć ojczyźnie wykorzystując swe uzdolnienia artystyczne, niż walczyć wręcz.

Generalną zasadą zakładania cmentarzy miała być ścisła harmonia $\mathrm{z}$ najbliższym otoczeniem. Starano się wykorzystywać walory naturalnego studied (the battlefield of Brzeziny) there are 44 documented sites: military cemeteries, sectors of other cemeteries, and individual graves or unmarked mounds (fig. 1); and about 50 unrecorded sites. Table 1 presents a catalogue and describes their present state as well as showing the results of field research undertaken between August 2002 and May 2003.

\section{THE ESTABLISHMENT OF WORLD WAR I CEMETERIES}

World War I took many innocent victims. The soldiers killed in the Łódź region came from opposing armies: Russians, Germans, Austrians, Hungarians, as well as Poles, Ukrainians, Slovaks, and Czechs. The problem of providing a decent place to bury them arose very quickly. In the Łódź region directly after the campaign the responsibility for cleaning up the battlefields was given to civilians and special military units, while specific institutions for organising military cemeteries appeared. As part of German and Austrian propaganda of that time however their activity was overrated and idealised. Special competitions were announced for chapel, gravestone and cross design. The sites of victorious battles to be visited by future generations were taken under particular care, and the process of establishing and organising them was similar in both German and Austrian occupation zones. The immediate start to the work was due to several factors but the main reasons were hygienic as unhygienic burials and polluted water had led to a risk of typhus, cholera and other contagious diseases spreading. Another argument for their quick construction was the opportunity to use a cheap workforce (prisoners of war and 'conscripted' artists) (SCHUBERT 1992) as many sculptors, architects or painters preferred to serve their country using their talents rather than fighting.

The general principle was to fit the cemetery into the surroundings using the landscape and as naturally as possible (KNERCER 1995). Cemeteries were very 
krajobrazu i rzeźbę terenu (KNERCER 1995). Bardzo często cmentarze lokowano w lesie lub na skraju lasu (Zgierz-Krogulec, Wiączyń Dolny, Poćwiardówka, Pawlikowice, Wymysłów Piaski, Witkowice, Konstantynów-Rszew Legionowo). Zalecano również lokalizację na lokalnych wyniesieniach terenu, co uwzględniono podczas tworzenia dwóch cmentarzy - w Gadce Starej i pod Konstantynowem Łódzkim (Rszew Legionowo).

Bardzo dużą wagę przywiązywano w zakładaniu cmentarzy do obsadzeń roślinnością. Szczególny nacisk kładziono na stosowanie krzewów i drzew rodzimych, co miało sprzyjać harmonii $\mathrm{z}$ terenem. Ponadto właściwie zastosowany materiał roślinny eksponował założenia cmentarne, a odpowiednio dobrane drzewa miały odgrywać rolę pomników w krajobrazie (KNERCER 1995). Preferowano świerki, tuje, dęby, klony i graby, a do obsadzania mogił i kwater używano barwinku i bluszczu. Zieleń wykorzystywano również na ogrodzenia cmentarne. Do mniejszych założeń stosowano żywopłoty z głogu, ligustru i tarniny (Poćwiardówka), a do większych świerki, tuje i graby (Kalino).

Przy zakładaniu cmentarzy preferowano proste założenia przestrzenno-kompozycyjne, wykorzystujące walory naturalnego krajobrazu i rzeźbę terenu (KNERCER 1995). Starano się tworzyć obiekty osiowo-symetryczne, dostosowane do otaczającego terenu lub już istniejących mogił, których nie chciano przenosić. Na badanym obszarze przeważały plany oparte na prostokątach i kwadratach (Wiączyń, Poćwiardówka, Witkowice, Zgierz Krogulec), a także na półkolach (Gadka Stara, Wymysłów Piaski). Obecnie pierwotne założenia cmentarne są mało widoczne, zatarte przez czas, jak również przez prace remontowe prowadzone w niektórych obiektach.

Ogrodzenie miało wydzielać miejsce pochówku żołnierzy z otoczenia, ale jednocześnie współgrać z krajobrazem. Dla większych cmentarzy proponowano mur kamienny (Gadka Stara) lub wał ziemny (Witkowice, Poćwiardówka), a dla mniejszych obiektów i mogił płoty z żeliwa (Wiączyń, Gałkówek, Dzierżązna, Witkowice) lub drewna (Zgierz-Krogulec, Zgierz Aniołów) (KNERCER 1995). Na obudowę pojedynczych mogił w obrębie cmentarza zalecano stosowanie kamieni. Popularną formą ogrodzenia były także żywopłoty z krzewów (Poćwiardówka) i drzew (Kalino). Często stosowano jednocześnie dwa rodzaje ogrodzenia. Zgodnie $\mathrm{z}$ wszelkimi instruk- often situated in or at the edge of a forest (Zgierz-Krogulec, Wiączyń Dolny, Poćwiardówka, Pawlikowice, Wymysłów Piaski and Witkowice, Konstantynów - Rszew Legionowo). A location on a local hill was also recommended, and actually followed at Gadka Stara and Rszew Legionowo (near Konstantynów Łódzki).

A lot of attention was paid to planting local types of low vegetation and trees to harmonise with the surrounding area. Appropriately arranged planting set off the cemetery with suitably selected trees performing a monumental role in the landscape (KNERCER 1995). Those usually selected were spruce, thuja, oak, maple and hornbeam, and the low vegetation used for individual graves and in sectors included periwinkle and ivy. Plants were also used for cemetery boundaries, smaller cemeteries were surrounded with hawthorn, privet and blackthorn hedges (Poćwiardówka) and for the larger, spruce, thuja and hornbeam were used (Kalino).

Simple spatial compositions were preferred using existing natural and landscape resources (KNERCER 1995). Cemeteries were usually designed symmetrically around an axis, and fitted to the surrounding area or already existing graves which people did not want to move. In the area studied most cemeteries were based on rectangles or squares (Wiączyń, Poćwiardówka, Witkowice and Zgierz Krogulec), as well as semi-circles (Gadka Stara and Wymysłow Piaski). At present due to passing time the original cemeteries are barely traceable, although some have been renovated.

The boundaries were to separate the soldiers' burial place from the surrounding area, but at the same time harmonise with the landscape. For larger cemeteries stone walls (Gadka Stara) or ditches (Witkowice and Poćwiardówka) were recommended, and for smaller ones and single graves, railings made from cast iron (Wiączyń, Galkowek, Dzierżazna and Witkowice) or wooden fences (Zgierz Krogulec and Zgierz Aniołów) (KNERCER 1995). For individual graves, stone was recommended. A popular form was a hedge (Poćwiardówka) or trees (Kalino) with the two often used simultan- 
cjami i odgórnymi nakazami wystrój cmentarzy miał być jednorodny, dopasowany do charakteru pochowanych na nim poległych. Nagrobki miały być skromne, jednakowe dla żołnierzy wrogich armii, a materiał budowlany miał bazować na lokalnych surowcach (FRODYMA 1989). W przypadku materiału budowlanego należy wyróżnić materiał pierwotny stosowany przy budowie cmentarzy (kamień polny, głaz narzutowy, beton, drewno, żeliwo) i materiał wtórny stosowany przy odnawianiach i upamiętnianiu niektórych obiektów (lastriko, marmur, granit, drewno, beton). Trzeba jednak zaznaczyć, że prace na wielu cmentarzach ograniczają się jedynie do uporządkowania terenu zajętego przez cmentarz. Nowy, wtórny material stosowany jest w zasadzie jedynie do upamiętnienia - postawienia obiektu centralnego lub tablicy pamiątkowej. Wyjątkiem jest cmentarz w lesie Krogulec w Zgierzu, który jest całkowicie odrestaurowany, i kwatera na cmentarzu rzymskokatolickim w Zgierzu, gdzie postawione są nowe nagrobki z lastrika.

Opisując stylistykę, wzięto pod uwagę wszystkie materialne elementy cmentarza, służące upamiętnieniu mogił i pochowanych w nich osób. Wyróżniamy: nagrobki, krzyże, podkreślające indywidualne i zbiorowe mogiły, a także obiekty centralne, upamiętniające wszystkich pochowanych na cmentarzu. Nagrobki najczęściej występują jako „pulpitowe” tabliczki nagrobne, stojące stele i głazy narzutowe. Wśród krzyży wyróżniono żeliwne, betonowe i drewniane. Największą różnorodnością odznaczają się obiekty centralne obeliski z kamieni zwieńczone krzyżem, duże drewniane krzyże, głazy narzutowe, drewniana kaplica w Gadce Starej (już nie istniejąca), nowe obeliski $\mathrm{z}$ betonu, lastrika.

Istnieje pewna zależność w sposobie upamiętniania pochowanych. W strefie okupacji austrowęgierskiej, dominującą formą są żeliwne i betonowe krzyże (fot. 1) (Kiełczówka, Wolbórz, Piotrków Trybunalski). Natomiast w strefie okupacji niemieckiej przeważają nagrobki betonowe i z kamienia (fot. 2). Wyjątkiem jest kwatera na cmentarzu prawosławnym w Łodzi, gdzie obok betonowych pomników pojawiają się także żeliwne krzyże.

Wartym uwagi elementem sa inskrypcje i epigrafy zarówno pierwotne, jak i wtórne. Inskrypcje wyryte są na obiektach centralnych, na nagrobkach $\mathrm{z}$ betonu i z kamienia. Inskrypcje dotyczą podstawowych informacji o poległych. Na obiek- eously. According to regulations, the cemetery decoration was supposed to be homogenous and appropriate for the buried soldiers. The gravestones were to be modest, identical for soldiers from opposing armies, and the building material was to come from local resources (FRODYMA 1989).

Materials include the original ones used for building the cemeteries (local stone, erratic boulders, concrete, wood and cast iron), and more recent material used for renovation and commemoration (mosaic, marble, granite, wood and concrete). It must be remembered, however, that work in many cemeteries is limited to cleaning the area. New more recent material is used only for a central monument or an inscribed memorial tablet. An exception is the completely renovated cemetery in the Krogulec forest in Zgierz, and a section of the Zgierz Roman Catholic cemetery where there are new mosaic gravestones.

The style is defined by all the physical elements serving as graves and commemorating those buried in them: gravestones, crosses marking individual and collective graves, as well as central monuments commemorating all who are buried in the cemetery. The gravestones are usually in 'pulpit' form, standing slabs or boulders, while crosses are of cast iron, concrete or wood. The widest variety is shown by central monuments - obelisks topped by stone crosses, large wooden crosses, boulders, in Gadka Stara a wooden chapel (no longer existing), or newer obelisks made of concrete with mosaic.

There is certain regularity in the way the dead are commemorated. In the AustroHungarian occupation zone cast-iron and concrete crosses dominate (photo 1) (Kiełczówka, Wolbórz and Piotrków Trybunalski), while in the German zone graves are mostly made of concrete and stone (photo 2 ). The only exception is the section of the Orthodox cemetery in Łódż where there are concrete monuments and also cast-iron crosses.

Inscriptions and individual epitaphs, both original and more recent, are worth mentioning on central monuments and individual gravestones and contain basic information about the dead soldiers. On 
tach centralnych, oprócz informacji o liczbie i narodowości pochowanych na danym cmentarzu, można odnaleźć również krótkie epigrafy, czyli napisy $\mathrm{w}$ formie motta lub dewizy, często $\mathrm{w}$ formie wierszowanej (Encyklopedia popularna PWN, 1994). central monuments, in addition to information about the number and nationality of the soldiers buried, short epitaphs can also be found i.e. texts in the form of a motto, often rhymed (Encyklopedia popularna PWN, 1994).

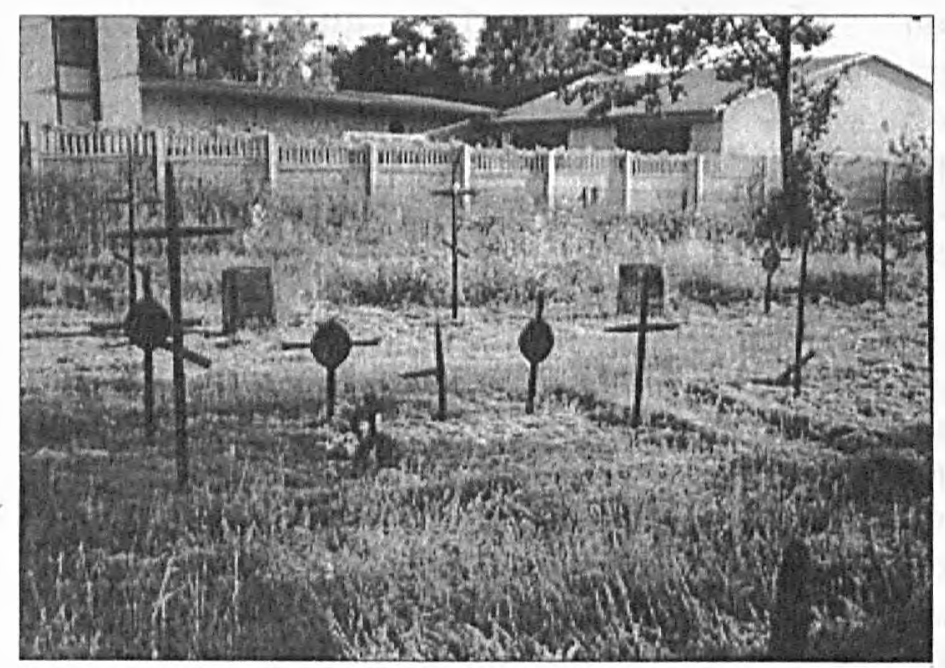

Fot. 1. Cmentarz w Kiełczówce (fot. autorka)

Photo 1. The cemetery in Kiełczówka (author's photograph)

Fot. 2. Cmentarz w Wymysłowie (fot. autorka)

Photo 2. The cemetery in Wymystów (author's photograph)

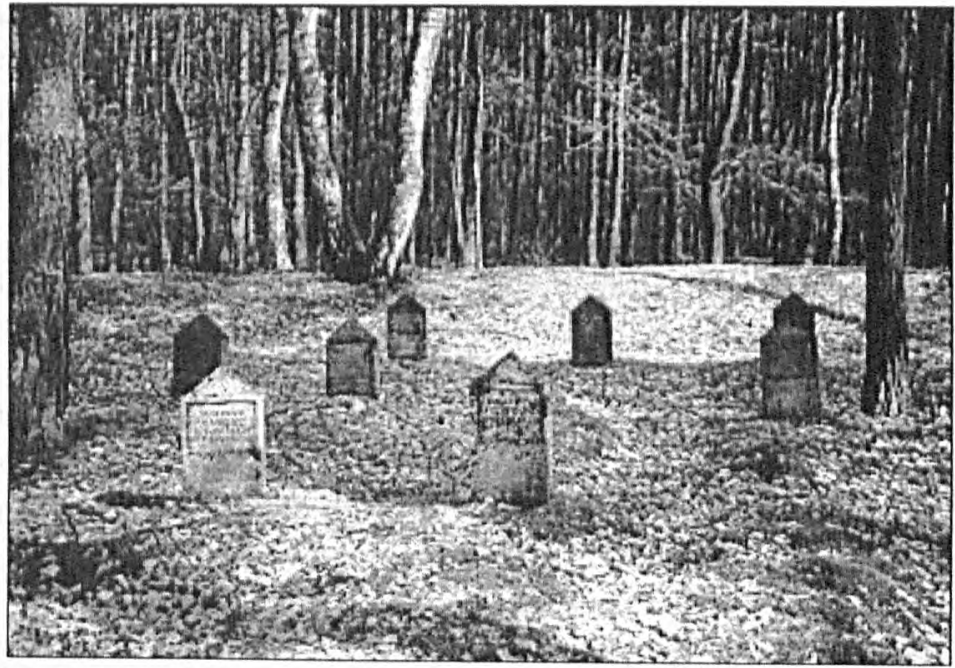

$\mathrm{Na}$ badanym obszarze pierwotne epigrafy zachowały się między innymi na obelisku kwatery żołnierskiej na cmentarzu ewangelickim $w$ Zgierzu i na obiekcie centralnym na cmentarzu wojskowym w Piotrkowie Trybunalskim. Oprócz inskrypcji pierwotnych na cmentarzach i kwaterach znaleźć można epigrafikę współczesną, umieszczoną na nowych tablicach pamiątkowych - np. na cmentarzu w Zgierzu w lesie Krogulec.

Cmentarze z okresu I wojny światowej na badanym obszarze nie należą do wyjątkowych obiektów tego typu. Nie odznaczają się taką różnorodnością form architektonicznych i założeń cmentarnych, jak pochodzące $\mathrm{z}$ tego samego okresu cmentarze w Beskidzie Niskim. Twórcy obiektów cmen-
In the study area, original epitaphs have been preserved on the obelisk of the soldiers' section at the Evangelical cemetery in Zgierz and on the central monument in the military cemetery in Piotrków Trybunalski. Apart from original inscriptions, modern epitaphs can be found on new gravestones e.g. in the cemetery in the Krogulec forest in Zgierz.

Cemeteries from World War I in this area are not exceptional and they do not display such a variety of architectural forms as those in the Beskid Niski. The artists working in cemeteries around 
tarnych okolic Łodzi korzystali z gotowych wzorów nagrobków i krzyży. W konsekwencji typologia tych elementów jest mało zróżnicowana, co sprawia, że mniejsze założenia cmentarne, a w szczególności kwatery na cmentarzach ewangelickich, są do siebie bardzo podobne. Niemniej jednak wszystkie zbadane obiekty odznaczają się dużym urokiem, charakterystycznym dla starych cmentarzy, a swoim wyrazem zmuszają do chwili refleksji nad tragiczną śmiercią żołnierską. Szczególnie dużą wartością i atrakcyjnością odznaczają się obiekty posiadające największą liczbę elementów pierwotnych. Bardzo dobrze ukazuje to waloryzacja przeprowadzona metodą bonitacji punktowej (WARSZYŃSKA 1971).

W celu przeprowadzenia waloryzacji opracowane zostały kryteria, według których poszczególnym obiektom nadano odpowiednią liczbę punktów (tab. I). Brane były pod uwagę cechy podstawowe, oceniane w skali 1-3, które wpływają na atrakcyjność turystyczną cmentarzy, a także cechy dodatkowe, podnoszące w szczególny sposób wartość badanych obiektów, za które obiekt otrzymywał dodatkowy jeden punkt. Wśród cech podstawowych najwyżej punktowane były pierwotne założenia cmentarne, nagrobki, krzyże, ogrodzenia i bramy, a także stan obecny, stopień zadbania i ewentualne prace restauracyjne przeprowadzone $\mathrm{w}$ obrębie obiektów, dostępność cmentarza i posiadanie przez niego tablicy informacyjnej. Cechy dodatkowo brane pod uwage to informacja w przewodniku, na mapie turystycznej, wpis do rejestru zabytków, niepowtarzalność i występowanie epigrafów.

Przeprowadzona waloryzacja pozwoliła określić atrakcyjność turystyczną poszczególnych obiektów. W tym celu obliczono średnią arytmetyczną sum bonitacyjnych (x), a następnie odchylenie standardowe. Wartość odchylenia standardowego została dodana i odjęta od średniej arytmetycznej i w ten sposób wydzielono cztery przedziały, którym przypisano odpowiednie rangi atrakcyjności turystycznej (od I do IV) (tab. I). Na podstawie otrzymanych wyników powstała mapa (rys. 2) przedstawiająca rozmieszczenie cmentarzy na obszarze badań i ich waloryzację. Mapa waloryzacyjna ukazuje stopień atrakcyjności obiektów cmentarnych z okresu I wojny światowej w okolicach Łodzi. Jak widać większość obiektów posiada średnie walory turystyczne $-61,4 \%, 22,7 \%$ obiektów charakteryzuje się walorami bardzo wysokimi, 6,8\% walorami wysokimi, a 9,1\% walorami niskimi. Miejsca pochówku o walorach bardzo wysokich to cmentarze bądź kwatery niedawno odnowione i uporządkowane. $\mathrm{Z}$ kolei obiekty o walorach bardzo niskich to cztery kwate-
Łódź used ready-made ideas for gravestones and crosses. As a consequence they are not varied, which makes smaller cemetery sections, and particularly those in Evangelical cemeteries, very similar one to another. However, all the studied sites have the charm typical of old cemeteries and encourage reflection on the soldier's tragic death. The most valuable and attractive are those with the largest number of original elements shown very clearly in the point scores and rankings (WARSZYŃSKA 1971).

To determine ranks, criteria were chosen and points scored (table 1). The ranking, on a 1-3 scale, was based on those features which affect the tourist attractiveness of cemeteries, as well as on additional features allowing the scoring an extra fourth point. Among basic features, points were given to already-existing cemeteries, gravestones, crosses, boundaries and gates, as well as to their present condition and possible restoration work, the accessibility of the cemetery and an available information board. The additional features taken into account were information in a guidebook, on a tourist map, an entry in the register of monuments, uniqueness and the presence of epitaphs.

The ranking determined the tourist attractiveness of an individual site. For this purpose the arithmetical mean (x) was calculated, followed by the standard deviation. The values of the standard deviation were added to and subtracted from the mean and in this way four tourist attractiveness ranks were identified (I-IV) (table 1). From the results a map was drawn (fig. 2) presenting the distribution of cemeteries in the area studied with their ranks and showing the degree of attractiveness. Most (61.4\%) were in rank III, $22.7 \%$ were very highly evaluated (rank I), 6.8\% - highly (rank II), and 9.1\% poorly (rank IV). Those very highly evaluated are whole cemeteries or individual sections which have recently been renovated or cleaned. Those poorly 
ry na cmentarzach ewangelickich. Wynika to $\mathrm{z}$ bardzo złej sytuacji cmentarzy ewangelickich na badanym obszarze. Są to obiekty bardzo często zdewastowane i rozkradzione, nic więc dziwnego, że kwatery wojskowe znajdujące się na nich uzyskały tak mało punktów w przeprowadzonej waloryzacji. evaluated were from four Evangelical cemeteries which have been plundered and damaged resulting in their very poor condition.
Rys. 2. Mapa waloryzacyina; proponowane szlaki turystyczne

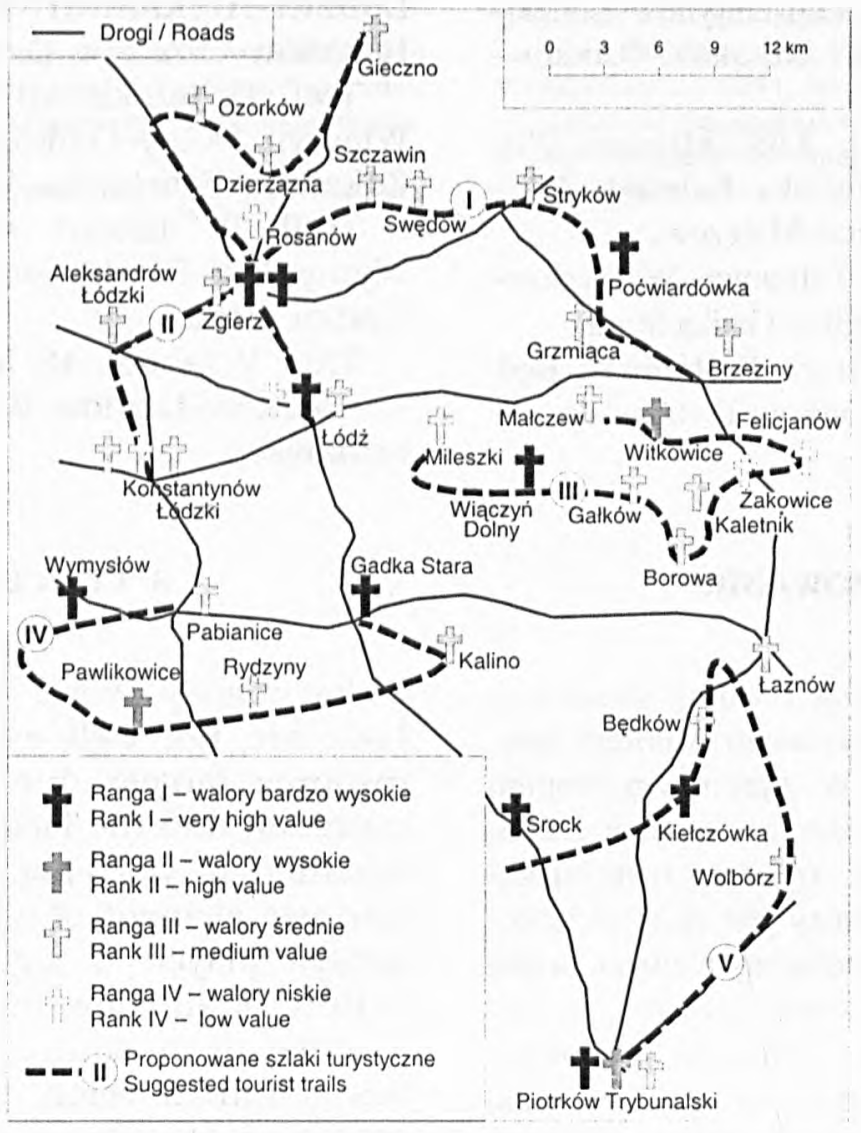

Fig. 2. Map of cemeteries ranked by tourist attractiveness with suggested tourist trails

\section{PROPOZYCJA SZLAKÓW TURYSTYCZNYCH}

Cmentarze $z$ okresu I wojny światowej są bardzo dużym potencjałem turystycznym okolic Łodzi. Aby je w pełni wykorzystać, należy przeprowadzić szereg prac restauracyjnych i porządkowych. Jednak i w obecnym stanie są to obiekty warte obejrzenia, posiadające ogromny urok starych cmentarzy, z ciekawymi nagrobkami i innymi elementami architektury cmentarnej. W związku z tym zaproponowano pięć szlaków turystycznych po miejscach pochówku z okresu I wojny światowej w okolicach Łodzi. Przebieg poszczególnych tras przedstawia załączona mapa (rys. 2).

\section{SUGGESTED TOURIST} TRAILS

Cemeteries from World War I have great tourist potential for areas near Łódż but in order to exploit them fully a lot of restoration and cleaning needs to be done. However, even in their present condition they are worth visiting with their old cemetery charm, their interesting graves and elements of cemetery architecture. As a result five tourist trails have been suggested, to take tourists to those cemeteries from the times of World War I, presented on a map (fig. 2). 
Każdy ze szlaków liczy powyżej 40 km, dlatego raczej niezbędny jest samochód. Do wędrówek pieszych bądź wycieczek rowerowych można wybrać sobie określone fragmenty szlaków.

Szlak I (ok. 43 km): Łódź-Zgierz-SzczawinSwędów-Stryków-Poćwiardówka-GrzmiącaBrzeziny.

Szlak II (ok. 45 km): Konstantynów ŁódzkiAleksandrów Łódzki-Zgierz-Rosanów-OzorkówDzierżązna-Gieczno.

Szlak III (ok. 43 km): Łódź-Mileszki-Wiączyń Dolny-Gałków-Borowa-Kaletnik-Żakowice-Felicjanów-Witkowice-Małczew.

Szlak IV (ok. 42 km): Pabianice-WymysłówPawlikowice-Rydzyny-Kalino-Gadka Stara.

Szlak V (ok. 48 km): Srock-Kiełczówka-Będków-Łaznów-Wolbórz-Piotrków Trybunalski.

\section{PODSUMOWANIE}

Obiekty cmentarne z okresu I wojny światowej, niestety, nie sa wykorzystywanym walorem turystycznym okolic Łodzi. W ogromnym stopniu przyczynia się do tego bardzo zły stopień zachowania tych obiektów, brak oznaczeń i informacji na ich temat. Taki stan rzeczy jest dość niepokojący, gdyż cmentarze - nieodłączny element każdej cywilizacji - zawsze odgrywały dużą rolę w kulturze każdej społeczności. Miejsce pochówku, grób - to rodzaj wiadomości: tu leży człowiek, należy zatem uszanować takie miejsce, gdyż tak nakazuje nam nasza kultura i religia. W szczególności winno się pamiętać o mogiłach i cmentarzach, na których spoczywają prochy cudzoziemców, którzy zostali pochowani na obcej ziemi. Po śmierci nie jest bowiem istotne, jakiej narodowości czy wiary był zmarły, gdyż każdemu człowiekowi należy się szacunek. Cmentarze są ponadto źródłem wiedzy o historii regionu, co potęguje ich atrakcyjność turystyczna. Tym bardziej cmentarze z I wojny światowej, czyli okresu nie najlepiej nam znanego, a niezmiernie ważnego, w wyniku którego po 123 latach Polska odzyskała niepodległość. Cmentarze wojenne z I woj.ny mogą być pouczającą lekcją historii o tamtych wydarzeniach. Aby jednak te obiekty stały się atrakcją turystyczna, należy przeprowadzić wiele prac porządkowych i remontowych, otoczyć je opieką zarówno społeczną jak i instytucjonalną, a także odpowiednio je promować.
Each of the trails is over $40 \mathrm{~km}$ long so the use of a car is advisable. For walking or cycling parts of a trail can be chosen.

Trail I (about $43 \mathrm{~km}$ ): Łódź-ZgierzSzczawin-Swędôw-Stryków-Poćwiardówka-Grzmiąca-Brzeziny.

Trail II (about 45km): Konstantynów Łódzki-Aleksandrów Łódzki-ZgierzRosanów-Ozorków-Dzierżązna-Gieczno.

Trail III (about $43 \mathrm{~km}$ ): Łódź-MileszkiWiączyń Dolny-Gałków-Borowa- KaletnikŻakowice-Felicjanów-Witkowice-Małczew.

Trail IV (about $42 \mathrm{~km}$ ): PabianiceWymysłów-Pawlikowice-Rydzyny-KalinoGadka Stara.

Trail V (about $48 \mathrm{~km}$ ): Srock-Kiełczówka-Będków-Łaznów-Wolbórz-Piotrków Trybunalski.

\section{CONCLUSIONS}

Unfortunately, World War I cemeteries near Łódź are not well exploited as a tourist resource largely due to their very poor condition and the lack of information. This situation is worrying, as cemeteries - an intrinsic element of all civilisations - have always played a significant role in the culture of all communities. A burial place, a grave, is a source of knowledge: here lies a human being; this place should be respected as culture and religion demand. The graves and cemeteries where foreigners are buried far from their own homelands should be particularly cared for. After death nationality or creed are not important and every individual deserves respect. In addition, cemeteries are sources of information about the history of a region and this increases their tourist attractiveness. This especially concerns those World War I cemeteries which Polish people are not very familiar with, but which are extremely important because as a result of this war Poland regained independence after 123 years. Military cemeteries from this time can be a history lesson about those events. However, in order to become tourist attractions, a lot of cleaning and renovation work must be done, they must be taken under institutional care, and promoted in an appropriate way. 


\section{BIBLIOGRAFIA - BIBLIOGRAPHY}

DABROWSKI J., 1937. Wielka Wojna 1914-1918, Księgarnia Trzaski, Everta i Michalskiego, Warszawa.

Encyklopedia popularna PWN, 1994, PWN, Warszawa.

FRODYMA R., 1989, Cmentarze wojskowe z okresu I wojny światowej $w$ rejonie Beskidu Niskiego i Pogórza. Komisja Wydawnicza Studenckiego Koła Przewodników Beskidzkich. Warszawa.

Knercer W.. 1995, Cmentarze wojenne z okresu I wojny światowej $w$ województwie olsztyńskim, Ośrodek Ochrony Zabytkowego Krajobrazu. Narodowa Instytucja Kultury, Warszawa.

KolbuszeWski J.,1996, Cmentarze, Wyd. Dolnoślaskie, Wrocław.
KOWALCZYK A., 2000, Geografia turyzmu, PWN, Warszawa.

LIJEWSKI T., MIKULOWSKI B., WYRZYKOWSKI J., 1985, Geografia turystyki Polski. PWN, Warszawa.

ROŻYCKI T., 1936, Brzeziny (19-24 XI 1914 r.), „ Bellona”, z. 1-2.

SCHUBERT J., 1992, Austriackie cmentarze wojenne w Galicji z lat 1914-1918. Wyd. „Secesja”. Kraków.

WARSZYŃSKA J., 1971, Waloryzacja miejscowości z punktu widzenia atrakcyjności turystycznej, .Zeszyty Naukowe Uniwersytetu Jagiellońskiego”, CCXLIX, „Prace Geograficzne", z. 27. 